\title{
Increasing Soybean (Glycine max. L.Merrill) Crop Production by Using Biourine and Organic Mulch
}

\author{
Ana Amiroh ${ }^{1 \bullet}$, Achmad Anton Prastyo ${ }^{1}$, Mahayu Woro Lestari ${ }^{2}$, Palupi Puspitorini ${ }^{3}$ \\ ${ }^{1}$ Faculty of Agriculture, Darul Ulum Lamongan Islamic University Jl. Airlangga 03 Sukodadi, Lamongan \\ ${ }^{2}$ Faculty of Agriculture, Islamic Malang University, Jl. Mayjen Haryono .193 Malang \\ ${ }^{3}$ Faculty of Agriculture, Balitar Islamic University, J1 Majapahit 04 Blitar \\ ${ }^{\bullet}$ Corresponding author email: anaamiroh@unisda.ac.id
}

\begin{abstract}
Soybean (Glycine max L.Merrill) is one of the main food commodities in Indonesia. The need for soybeans continues to increase in line with the increasing population of Indonesia. Overcome the problem of the gap between soybean production and consumption, efforts can be made to increase soybean production through fertilizers. Apart from fertilizers, mulching is an important component in efforts to increase plant growth and yield. Therefore, liquid organic fertilizer and organic mulch are the right innovations to be applied to support the growth and production of these soybean plants. The research method used was a randomized block design (RBD) with a factorial pattern with 3 replications, which consisted of 2 factors. The first factor was Liquid Organic Fertilizer (P) consisting of 3 levels, namely P1 (cow urine), P2 (goat urine), P3 (rabbit urine). The second factor was kinds of organic mulch with 3 levels, namely M0 (no mulch), M1 (straw mulch), M2 (husk mulch). The purpose of this study was to determine the effect of livestock bio urine and organic mulch on the growth and production of soybean (Glycine max. L.Merrill). From the results of observations and calculations through analysis of variance, it can be concluded that the ones that give high production are the treatment of Rabbit Urine Liquid Organic Fertilizer and Organic Straw Mulch (P3M1).
\end{abstract}

Keywords: growth; liquid fertilizer; organic mulch; soybean; yield

\section{INTRODUCTION}

Soybean (Glycine max L. Merril. Merril) is a plant that has a high protein content. Soybean is used as an ingredient in making tempeh, tofu, taucho etc. Currently, although soybean production has increased, it has not been able to meet domestic needs so it is still needed imports from other countries (Jayasumarta, 2015).

The low soybean productivity is thought to be the result of: (1). The presence of gum which can be a competitor for soybean plants, (2) Generally, soybean plants are cultivated in the marengan season, which is a tradition between the rainy season and the dry season, so that water needs are limited to support optimal growth, one of the cultivation techniques to increase soybean plant production. The maximum is by modifying the microclimate around the plant, namely by using mulch. Application of suitable mulch can change the soil microclimate so that it can increase soil moisture content and suppress the growth of weeds, one of the agricultural wastes that can be used as mulch, namely rice straw (Dewantari, et al.2015).

The need for soybeans continues to increase in line with the increasing population of Indonesia and the types of processed soybeans. Fertilizer is the main means of production that affects crop yields, because of its large role, the use of fertilizers in Indonesia in the last decade has increased rapidly. However, the use of chemical fertilizers for a relatively long time can cause the soil to harden quickly, be less able to store water, and quickly become acidic, which in turn will reduce plant productivity. The form of liquid organic fertilizer in the form of a liquid can make it easier for plants to absorb the nutrient elements contained in it compared to other solid fertilizers (Sembiring et al 2017).

To solve the gap problems low productivity of the soybean plant is thought to be the result of (1) the presence of weeds that can become competitors for soybean plants, (2) generally soybean plants are cultivated in the he March season which is a change in the dry season, means that the water needs are very limited for optimal plant growth. One of the cultivation techniques to increase soybean crop yields 
optimally is to manipulate the climate around the planc by using mulch.. The application of suitable mulch can change the soil microclimate so that it can increase soil moisture content and suppress weed growth. One of the agricultural wastes that can be used as mulch is rice straw. between the production and consumption of soybeans, efforts can be made to increase soybean production through liquid organic fertilizers. Liquid organic fertilizers (POC) are beneficial because they do not damage the soil and plants even though they are used as often as possible. Also, POC has a binding agent, so that the fertilizer solution applied to the soil surface can be used directly by plants. The application of liquid biological fertilizers significantly increases the growth and yield of shallots (Purba et al., 2020). Fertilizer urine from livestock varies, one of which is rabbit urine. The use of POC can solve environmental problems and help address the scarcity and high price of inorganic fertilizers today. Fertilizer urine from livestock varies, one of which is rabbit urine. Rabbits can produce feces or feces and urine in large quantities but are not widely used by rabbit breeders. (Sembiring., et al. 2017). For plant survival, food nutrition is needed which can be done by applying fertilizers either through soil or leaves. Plants also need food or nutrients for their survival. Fulfillment of nutrition can be done by fertilizing, either applying fertilizer directly through the soil which will then be absorbed by plant roots, or spraying on the leaves (Amiroh, 2017).

The system of utilizing livestock waste as organic fertilizer for agricultural crops is increasingly developing, but only a few farmers apply it. The rate of growth and plant production is determined by the nutrients absorbed by the plant. One of the efforts to increase plant production is through the addition of nutrients to plants through planting media, among others, through organic methods Rabbit urine is a liquid organic fertilizer which has advantages in both micro and macronutrient content exceeding the content of cow, goat, and sheep urine. (Gustia, 2017).

Apart from fertilizers, mulching is an important component in efforts to increase plant growth and yield. Mulch is a material or material that is used to cover the surface of the soil or agricultural land with specific purposes and objectives whose principle is to increase crop production. The factor that causes reduced soybean production is weeds. Weeds become nuisance plants that become competitors for cultivated plants, both in terms of space utilization, light and in terms of water and nutrient absorption. The presence of weeds in soybean crops cannot be avoided, resulting in competition and allelopathic content that can inhibit growth (Bardiana, et al. 2020).

Mulch which has been commonly used in agricultural cultivation can be in the form of organic mulch or synthetic mulch. Straw should be used for mulching, if the straw is burned, there will be a potential loss of organic matter from the soil (Muliartha and Purba, 2020). Organic mulch is in the form of straw, husks, reeds, and so on, while synthetic mulch is in the form of plastic mulch. Straw should be used for mulching, if the straw is burned, there will be a potential loss of organic matter from the soil (. The recommended thickness of the organic mulch layer is between $5-10 \mathrm{~cm}$. Mulch that is too thin will be less effective at controlling weeds. Meanwhile, according to. Plants also need food or nutrients for their survival. Fulfillment of nutrition can be done by fertilizing, either applying fertilizer directly through the soil which will then be absorbed by plant roots or spraying on the leaves (Amiroh. 2017).

Soil moisture and optimal soil temperature will affect the availability of water under the soil. These conditions are very beneficial for plants that affect the growth and fruit formation phases. (Pradoto, et al. 2017). Different uses of mulch will have different effects on soybean growth and yield. Other 
types of organic mulch such as straw and husks are very easy to obtain and easy to install.

From the description above, it is not certain that the use of liquid organic fertilizers and organic mulch is suitable for the growth and yield of soybeans and the interaction between liquid organic fertilizers and organic mulches (Sudarmin, et al, 2016) which are suitable for growth and yield of soybeans, therefore it is necessary to conduct a series of studies.

This study aims to determine the effect of liquid urien organic fertilizer for livestock and what types of organic mulch can provide maximum results on growth and soybean production. Also, to determine whether the interaction between the two factors is real.

\section{METHODS}

Time and place of research

This research was conducted in Dusun Kebondalem, Sumengko Village, Kedungpring District, Lamongan Regency. Altitude \pm 50 masl. The time of research was carried out from January to March 2019.

Research materials and tools

The materials and tools used were Anjasmoro soybean seeds. Liquid Organic Fertilizer used comes from the urine of cattle, goats, and rabbits that have been completely decomposed. Mulch used straw and rice husks. The tools used are jerry cans, plastic hose, hand sprayer, hoe, tugal, tape measure, scale, nameplate, writing tools, sieve wire, glassing sack, member, shovels, and buckets.

\section{Research methods}

This research was conducted using a factorial randomized block design (RBD), which consists of two factors and each factor consists of 3 levels, namely factor I: Kinds of Liquid Organic Fertilizer (P) with 3 levels: P1 (Cow Urine), P2 (Goat Urine), P3 (Rabbit urine). Factor II: Kinds of Organic Mulch with 3 levels: M0 (No Mulch), M1 (Straw Mulch), M2 (Husk Mulch). From these two factors, 9 treatment combinations were obtained and repeated 3 times so that there were 27 experimental units.

Research implementation

Making Liquid Organic Fertilizer (POC)

Liquid Organic Fertilizer (POC) was made by the researchers themselves with the following ingredients: 10 liters of cow, goat, and rabbit urine, 3 cups measuring $220 \mathrm{ml}$ EM4, 3 cups measuring $220 \mathrm{ml}$ molasses, 6 sachets of shrimp paste. The tools used: 3 jerry cans with a capacity of more than 10 liters, 3 plastic hoses each with a size of $50 \mathrm{~cm}$, a mixer made of wood.

Soil processing

Tillage is done by plowing or hoeing, making channels and plots, and leveling the land. The plot is made with a size of 2 meters x 2 meters. Each distance or block in the experiment is limited to a width of $50 \mathrm{~cm}$ and a depth of $20 \mathrm{~cm}$ so that when it rains the plants will not be inundated because the soil is good enough for planting.

Apply fertilizer

Basic fertilizers using petrochemical fertilizers are given with recommended doses ranging from 20 tonnes/ha and husk charcoal (biochar) with a composition of 2.5 tonnes/ha. Giving is done a week before planting. Provision of Liquid Organic Fertilizer given 1 mst and at intervals of once a week until the age of 42 dap.

Planting

The planting hole was made in a hole with a depth of $3 \mathrm{~cm}$ with a spacing of $30 \mathrm{~cm} \times 30$ $\mathrm{cm}$. Each hole is planted with 2 soybean seeds, then backfilled with soil.

Mulching

Organic mulch, namely straw, and husks were carried out 10 days after planting. Organic mulch is given 10 days after planting. It is not possible after planting the seeds to do the mulching because it is feared that the seeds cannot grow to break through the thickness of the mulch.

Maintenance 
Embroidering is done to replace dead, wilted, damaged, or poorly growing plants. Stitching is done 7 days after planting. Weeding is done once every 2 weeks and at the same time weeding it. Pest and disease control Harvesting

Harvesting is done with the criteria that the pods are fully filled, the leaves have turned yellow and are starting to fall and the color of the pods has turned brown.

Observation

The parameters observed in this study were 1) plant height $(\mathrm{cm})$, measured from the base of the stem to the top of the plant begins; 2) number of leaves, counted from the starting leaf that has opened perfectly, 3) step fresh weight $(\mathrm{g})$, weigh all parts of the plant, which is done at harvest, 4) stunted dry weight (g), weigh all parts of the plant that have been dried in an oven at $600 \mathrm{C}$ for $3 \times 24$ hours or until they reach a constant weight., 5) dry seed weight per sample (g), weighing the dry seed weight per sample plant, 6) dry seed weight per plot (g), weighing all dry seeds in the plot in each experimental unit, 7) weight of 1000 dry seeds (g), weighing the weight of 1000 dry seeds per experimental plot.

Data processing

Data analysis used variance with Fisher's test (-F test at 5\% and 1\% levels). If there is a real difference, it will be followed by the least significant difference test (LSD 5\%).

\section{RESULTS AND DISCUSSION}

The successful growth of a plant is influenced by two important factors, namely genetic factors related to the inheritance of the plant and environmental factors related to the environmental conditions in which the plant grows. If it is known that genetic factors are not a constraint in growth, plant growth is only controlled by environmental factors (Dewantari, et al, 2015).

The use of rabbit urine fertilizer is expected to reduce the use of inorganic fertilizers. The continuous use of inorganic fertilizers has a bad impact and is not environmentally friendly, Nurmasyitah, et al, (2013) stated that fertilization carried out through the soil is influenced by the low $\mathrm{P}$ content available in the soil is also caused by the reaction of the soil which is very acidic to acidic and the increase in AL content which can interchangeable. With the high AL in the soil, it can bind $\mathrm{P}$ in the form of AL-P which makes it difficult for $\mathrm{P}$ in the soil to be available for absorption by plants, the very low $\mathrm{P}$ availability is due to $\mathrm{pH}$ low soil increased $\mathrm{Al}, \mathrm{Fe}$, and $\mathrm{Mn}$ ions in soil solution, increased $\mathrm{Ca}$ availability, the amount and level of decomposition of low organic matter and microorganism activities.

Plant height

The results of the analysis of variance showed significantly different results in the treatment of various kinds of organic mulch on plant height growth at 14 days and 28 days of age observation and there was an interaction between the two factors at the 42 dast age observation. Can be seen in the table 1 .

Table 1. Average plant height $(\mathrm{cm})$ at age observations

\begin{tabular}{cll}
\hline \multirow{2}{*}{$\begin{array}{c}\text { Treatment } \\
\text { Mulching) }\end{array}$} & \multicolumn{2}{c}{ Plant Height (cm) } \\
\cline { 2 - 3 } & 14 DAP & 28 DAP \\
\hline M0 (no mulch) & $41.00 \mathrm{c}$ & $94.87 \mathrm{c}$ \\
\hline M1 (straw mulch) & $45.33 \mathrm{a}$ & $114.80 \mathrm{a}$ \\
\hline M2 (husk mulch) & $44.20 \mathrm{ab}$ & $104.73 \mathrm{~b}$ \\
\hline LSD 5\% & 1.85 & 4.37
\end{tabular}

Notes: The numbers followed by the same letter in the same column are not significantly different from the 5\% LSD test.

In table 1, it can be seen that the observation of plant height parameters at the age of 14 and 28 DAP is significantly different in the treatment of various kinds of mulch but there is no interaction between kinds of liquid organic fertilizers and organic mulch. 
For plant height variables at the age of 14 and 28 DAS, the effect of various kinds of mulch and liquid organic fertilizer was not significant. This is because the plants are still young and still in the early stages of growth, so the plants still use the food reserves found in the seeds. Also, plants have not been able to absorb nutrients from the soil because the roots that are formed are not functioning properly which results in less optimal absorption of nutrients. Whereas in young plants, the root system is not yet perfect in function or distribution.

Table 2. Average Plant Height $(\mathrm{cm})$ in Age observations

\begin{tabular}{ll}
\hline \multicolumn{1}{c}{$\begin{array}{c}\text { Treatment } \\
\text { (Mulching) }\end{array}$} & \multicolumn{1}{c}{$\begin{array}{c}\text { Plant } \\
\text { Height }(\mathrm{cm})\end{array}$} \\
\cline { 2 - 2 } & \multicolumn{1}{c}{$42 \mathrm{DAP}$} \\
\hline $\begin{array}{l}\text { P1M0 (cow urine and no } \\
\text { mulch) }\end{array}$ & $60.87 \mathrm{ghi}$ \\
\hline $\begin{array}{l}\text { P1M1(cow urine and straw } \\
\text { mulch) }\end{array}$ & $67.13 \mathrm{def}$ \\
\hline $\begin{array}{l}\text { P1M2 (cow urine and husk } \\
\text { mulch) }\end{array}$ & $62.80 \mathrm{efgh}$ \\
\hline $\begin{array}{l}\text { P2M0 (goat urine and no } \\
\text { mulch) }\end{array}$ & $64.20 \mathrm{defg}$ \\
\hline $\begin{array}{l}\text { P2M1 (goat urine and straw } \\
\text { mulch) }\end{array}$ & $70.07 \mathrm{~cd}$ \\
\hline $\begin{array}{l}\text { P2M2(goat urine and husk } \\
\text { mulch) }\end{array}$ & $68.33 \mathrm{cde}$ \\
\hline $\begin{array}{l}\text { P3M0 (rabbit urine and no } \\
\text { mulch) }\end{array}$ & $71.73 \mathrm{bc}$ \\
\hline $\begin{array}{l}\text { P3M1(rabbit urine and straw } \\
\text { mulch) }\end{array}$ & $92.13 \mathrm{a}$ \\
\hline $\begin{array}{l}\text { P3M2 (rabbit urine and husk } \\
\text { mulch) }\end{array}$ & $76.33 \mathrm{~b}$ \\
\hline LSD 5\% & 5.98 \\
\hline Non The no
\end{tabular}

Notes: The numbers followed by the same letter in the same column are not significantly different from the 5\% LSD test.

In Table 2, it can be seen that the observation of plant height parameters at the age of 42 DAP showed the interaction of rabbit urine liquid organic fertilizer (P3) and straw organic mulch (M1). This is indicated by the highest value compared to other treatments.

Table 3. Average number of leaves (strands) at age.

\begin{tabular}{|c|c|c|c|}
\hline \multirow[b]{2}{*}{ Treatment } & \multicolumn{3}{|c|}{ Number of leaves } \\
\hline & $\begin{array}{c}14 \\
\text { DAP }\end{array}$ & $\begin{array}{c}28 \\
\text { DAP }\end{array}$ & $\begin{array}{c}42 \\
\text { DAP }\end{array}$ \\
\hline $\begin{array}{l}\text { P1M0 (cow } \\
\text { urine and no } \\
\text { mulch) }\end{array}$ & 6.27 & 15.13 & 31.80 \\
\hline $\begin{array}{l}\text { P1M1(cow } \\
\text { urine and } \\
\text { straw mulch) }\end{array}$ & 6.40 & 15.07 & 32.67 \\
\hline $\begin{array}{l}\text { P1M2 (cow } \\
\text { urine and husk } \\
\text { mulch) }\end{array}$ & 6.67 & 15.27 & 31.73 \\
\hline $\begin{array}{l}\text { P2M0 (goat } \\
\text { urine and no } \\
\text { mulch) }\end{array}$ & 6.87 & 15.73 & 31.93 \\
\hline $\begin{array}{l}\text { P2M1 (goat } \\
\text { urine and } \\
\text { straw mulch) }\end{array}$ & 6.27 & 16.13 & 32.00 \\
\hline $\begin{array}{l}\text { P2M2 (goat } \\
\text { urine and husk } \\
\text { mulch }\end{array}$ & 6.80 & 16.27 & 32.07 \\
\hline $\begin{array}{l}\text { P3M0 (rabbit } \\
\text { urine and no } \\
\text { mulch) }\end{array}$ & 6.93 & 16.00 & 32.27 \\
\hline $\begin{array}{l}\text { P3M1 (rabbit } \\
\text { urine and } \\
\text { straw mulch) }\end{array}$ & 7.07 & 17.07 & 33.73 \\
\hline $\begin{array}{l}\text { P3M2 (rabbit } \\
\text { urine and husk } \\
\text { mulch) }\end{array}$ & 7.00 & 16.73 & 32.40 \\
\hline LSD 5\% & NS & NS & NS \\
\hline
\end{tabular}

Notes: The numbers followed by the same letter in the same column are not significantly different from the 5\% LSD test.

Soybean plants at the age of 42 DAP showed significant differences in the treatment of rabbit urine liquid organic fertilizer, can be seen in table 2, that the mean of each treatment, the use of rabbit liquid organic fertilizer received the highest value than cow urine or 
goat urine liquid organic fertilizer. The high value can be predicted because in the rabbit urine POC, there are nutrients needed by soybean plants, available in sufficient and balanced quantities so that it can trigger better growth and yield.

\section{Number of Leaves}

The results of the analysis of variance showed that there was no interaction between treatments of various kinds of liquid organic fertilizers and organic mulch on the growth in the number of leaves at each observation at the age of 14 days, 28 days, and 42 days. This can be seen in table 4 .

In table 3. It can be seen that the observation of the number of leaves parameters starting at the age of 14 days, 28 days, and 42 days, does not show any interaction with the treatment of various kinds of liquid organic fertilizers and organic mulch. The best values were in the treatment of rabbit urine liquid organic fertilizer (P3) and organic straw mulch $(\mathrm{P} 2)$, this is indicated by the highest value compared to other treatments.

It is assumed that each treatment given can provide sufficient nutrients for soybean plants so that the process of forming leaf vegetative organs in plants runs optimally.

Stover Fresh Weight

Table 4. Average plant fresh weight (g).

Treatment

(kinds of liquid Fresh weight (g) organic)

\begin{tabular}{cc}
\hline P1 (cow urine) & $336.67 \mathrm{c}$ \\
\hline P2 (goat urine) & $538.67 \mathrm{ab}$ \\
\hline P3 (rabbit urine) & $546.00 \mathrm{a}$ \\
\hline LSD 5\% & 82,143 \\
\hline
\end{tabular}

Notes: The numbers followed by the same letter in the same column are not significantly different from the 5\% LSD test.

The results of the analysis of variance showed that there were significantly different results in the treatment of various kinds of liquid organic fertilizers to the weight of the plant's fresh stover at harvest. This can be seen in table 4.

In table 4 , it can be seen that the observations of the fresh stover weight parameters of the plants were significantly different in the liquid organic fertilizer treatment but there was no interaction between the liquid organic fertilizer treatment and the kinds of organic mulch.

This is presumably because in the vegetative phase of the plant (plant height to leaf area index) soybean plants get sufficient nutrient intake so that photosynthesis can run smoothly so that the results of photosynthesis (glucose) are converted into carbohydrates, proteins, and fats which are accumulated into pods. which results in the soybean seeds pithy or filled. This shows that the higher the concentration, the more nutrient content is added to the soil. Availability of nutrients in the soil will support plant growth as a result, plants can grow optimally.

The addition of organic fertilizers such as kendang fertilizer to the soil can improve soil aggregation so that it can increase the number of soil pores so that the soil becomes looser and eventually becomes a suitable medium for plant growth because root growth is wider and nutrient absorption is better, nitrogen is needed by soybean plants. in the growth process, especially during the vegetative growth period (Utami, et al 2020; Parmila, et al. 2019).

Dry Stover Weight

The results of the analysis of variance showed that there were significantly different results in the treatment of various kinds of liquid organic fertilizers and organic mulch to the dry weight of plant stover at harvest time. This can be seen in table 6 .

In table 5. It can be seen that there are significantly different results in the treatment of various kinds of liquid organic fertilizers and kinds of organic mulch on the dry weight of plants at harvest, but there is no interaction between treatments of various kinds of liquid fertilizers and organic mulches. 
Table 5. Average stover dry weight (g)

\begin{tabular}{lc}
\hline Treatment & $\begin{array}{c}\text { Average plant dry } \\
\text { weight }(\mathrm{g})\end{array}$ \\
\hline P1 (cow urine) & $257.67 \mathrm{c}$ \\
P2 (goat urine) & $338.67 \mathrm{ab}$ \\
P3 (rabbit urine) & $343.67 \mathrm{a}$ \\
\hline LSD 5\% & 12.09 \\
\hline M0 (no mulch) & $287.67 \mathrm{c}$ \\
M1 (straw mulch) & $346.00 \mathrm{a}$ \\
M2 ( husk mulch) & $306.33 \mathrm{~b}$ \\
\hline LSD 5\% & 12.09
\end{tabular}

Notes: The numbers followed by the same letter in the same column are not significantly different from the 5\% LSD test.

This is because the dry stover weight of the plant is related to the fresh stover weight of the plant. Also, because the availability of water affects the process of forming plant organs such as leaves, stems, and roots. The amount of absorption of nutrients and water as materials for the photosynthesis process affects the fresh and dry weight of plants. Fungus inoculation greatly affects the dry weight and fresh weight of plants because fungi have hyphae that can absorb nutrients and water better.

Planted Seed Weight

Table 6. Average seed weight (g)

\begin{tabular}{lc}
$\begin{array}{c}\text { Treatment (Kinds } \\
\text { of Liquid organic) }\end{array}$ & $\begin{array}{c}\text { Average seed } \\
\text { weight per plant } \\
(\mathrm{g})\end{array}$ \\
\hline P1 (cow urine) & $81.33 \mathrm{c}$ \\
P2 (goat urine) & $134.67 \mathrm{ab}$ \\
P3 (rabbit urine) & $140.73 \mathrm{a}$ \\
\hline LSD 5\% & 7.37 \\
\hline M0 (no mulch) & $108.00 \mathrm{c}$ \\
M1 (straw mulch) & $136.07 \mathrm{a}$ \\
M2 (husk mulch) & $112.67 \mathrm{~b}$ \\
\hline LSD 5\% & 7.37 \\
\hline
\end{tabular}

Notes: The numbers followed by the same letter in the same column are not significantly different from the 5\% LSD test.

The results of the analysis of variance showed that there were significantly different results in the treatment of various kinds of liquid organic fertilizers and kinds of organic mulch on the weight of the seeds planted in each observation. This can be seen in table 6 .

In table 6 . It can be seen that there are significantly different results in the treatment of various kinds of liquid organic fertilizers and kinds of organic mulch on the weight of the seeds at harvest time, but there is no interaction between the treatments of liquid organic fertilizers and organic mulch.

The dry weight reflects the accumulation of organic compounds that have been successfully synthesized by plants from organic compounds. If the rate of photosynthesis goes well, the photosynthate produced in biomass such as roots, stems, and leaves will increase (Utami, et al, 2020).

Table 7. Average seed weight per plot (g)

\begin{tabular}{ll}
\multicolumn{1}{c}{ Treatment } & \multicolumn{1}{c}{$\begin{array}{c}\text { Average } \\
\text { Seed } \\
\text { Weight per } \\
\text { plot (g) }\end{array}$} \\
\hline $\begin{array}{l}\text { P1M0 (cow urine and no } \\
\text { mulch) }\end{array}$ & $313.33 \mathrm{gh}$ \\
\hline $\begin{array}{l}\text { P1M1 (cow urine and } \\
\text { straw mulch) }\end{array}$ & $466.67 \mathrm{cde}$ \\
\hline $\begin{array}{l}\text { P1M2 (cow urine and husk } \\
\text { mulch) }\end{array}$ & $386.67 \mathrm{e}$ \\
\hline $\begin{array}{l}\text { P2M0 (goat urine and no } \\
\text { mulch) }\end{array}$ & $473.33 \mathrm{~cd}$ \\
\hline $\begin{array}{l}\text { P2M1 (goat urine and } \\
\text { straw mulch) }\end{array}$ & $313.33 \mathrm{gh}$ \\
\hline $\begin{array}{l}\text { P2M2 (goat urine and } \\
\text { husk mulch) }\end{array}$ & $353.33 \mathrm{c}$ \\
\hline $\begin{array}{l}\text { P3M0 (rabbit urine and no } \\
\text { mulch) }\end{array}$ & $520.00 \mathrm{fg}$ \\
\hline $\begin{array}{l}\text { P3M1 (rabbit urine and } \\
\text { straw mulch) }\end{array}$ & $626.67 \mathrm{a}$ \\
\hline $\begin{array}{l}\text { P3M2 (rabbit urine and } \\
\text { husk mulch) }\end{array}$ & $613.33 \mathrm{ab}$ \\
\hline LSD 5\% & 60.61 \\
\hline
\end{tabular}

Notes: The numbers followed by the same letter in the same column are not significantly different from the 5\% LSD test.

The carbohydrate, protein, and other compounds in the seeds affect the weight of the 
seeds. The $\mathrm{N}$ element contained in liquid organic fertilizers is a constituent of organic matter in seeds such as amino acids, proteins, coenzymes, chlorophyll, and some other ingredients in seeds so that the application of fertilizers containing $\mathrm{N}$ to plants will increase the dry weight of the seeds.

Seed weight per plot

The results of the analysis of variance showed that there was an interaction between the types of liquid organic fertilizers and the kinds of organic mulch on the weight of the seeds per plot at harvest. This can be seen in table 7.

In table 7, it can be seen that the highest average seed weight value was obtained from the treatment of rabbit urine liquid organic fertilizer and straw mulch (P3M1). While the lowest value was obtained from the combination of P1M0 treatment, namely the treatment of cow urine liquid organic fertilizer and without mulch.

Liquid organic fertilizers contain elements needed by soybean plants. Also, this organic nature can provide organic compounds that are natural and safe for the environment, as well as for its users. Liquid fertilizers are more easily absorbed by plants because the elements in them have broken down. Plants absorb nutrients mainly through the roots, but the leaves also can absorb nutrients so that there are benefits if liquid fertilizer is not only applied around the plant but also on the leaves. The use of liquid fertilizers makes the job easier, and the use of liquid fertilizers means that you can carry out three kinds of processes at once, namely fertilizing plants, watering plants, and treating plants.

Cities and settlements are currently showing the development of waste and waste which has increased drastically, most of which organic waste if properly composed can be used as organic fertilizer (Suwarno, 2009).

Application of organic mulch can increase the soil organic $\mathrm{C}$ content compared to the natural soil conditions before the experiment.
The increase in organic $\mathrm{C}$ content for the dry season was $0.24-0.43 \%$. The process of decomposition of organic matter is initiated by microorganisms that change the form of longchain polysaccharides into short-chain saccharides which are relatively fast in releasing their nutrients.

Weight of 1000 grains of dry seeds

The results of the analysis of variance showed that there was an interaction between the treatment of liquid organic fertilizers and kinds of organic mulch on the weight of 1000 dry seeds at harvest. This can be seen in table 8

Table 8. Average weight of 1000 dry seeds per experimental plot

\begin{tabular}{lc}
\hline \multicolumn{1}{c}{ Treatment } & $\begin{array}{c}\text { Average weight } \\
\text { of } 1000 \text { dry } \\
\text { seeds (g) }\end{array}$ \\
\hline $\begin{array}{l}\text { P1M0 (cow urine and no } \\
\text { mulch) }\end{array}$ & 175.33 def \\
\hline $\begin{array}{l}\text { P1M1 (cow urine and straw } \\
\text { mulch) }\end{array}$ & 161.33 efgh \\
\hline $\begin{array}{l}\text { P1M2 (cow urine and husk } \\
\text { mulch) }\end{array}$ & 183.33 de \\
\hline $\begin{array}{l}\text { P2M0 (goat urine and no } \\
\text { mulch) }\end{array}$ & $198.67 \mathrm{bcd}$ \\
\hline $\begin{array}{l}\text { P2M1 (goat urine and straw } \\
\text { mulch) }\end{array}$ & $165.33 \mathrm{efg}$ \\
\hline $\begin{array}{l}\text { P2M2 (goat urine and husk } \\
\text { mulch) }\end{array}$ & $214.67 \mathrm{bc}$ \\
\hline $\begin{array}{l}\text { P3M0 (rabbit urine and no } \\
\text { mulch) }\end{array}$ & $175.33 \mathrm{def}$ \\
\hline $\begin{array}{l}\text { P3M1 (rabbit urine and } \\
\text { straw mulch) }\end{array}$ & $253.33 \mathrm{a}$ \\
\hline $\begin{array}{l}\text { P3M2 (rabbit urine and husk } \\
\text { mulch) }\end{array}$ & $222.00 \mathrm{~b}$ \\
\hline \multicolumn{1}{c}{ LSD 5\% } & 29,018 \\
\hline
\end{tabular}

Notes: The numbers followed by the same letter in the same column are not significantly different from the 5\% LSD test.

In table 8 , it can be seen that the observation of the parameters of the average weight of 1000 dry seeds per plot did not show 
any interaction with the treatment of various kinds of liquid organic fertilizers and kinds of organic mulch. The best values were in the treatment of rabbit urine liquid organic fertilizer (P3) and organic straw mulch (M1), this was indicated by the highest value compared to other treatments. The POC concentration had no significant effect on the dry weight of 100 seeds, the dry weight of seeds per sample. Mulching treatment caused a decrease in soil $\mathrm{pH}$ from 6.4 to 6.2. Even at the end of the observation the $\mathrm{pH}$ fell 0.3 points from 6.5 to 6.2. The cause of the drop in $\mathrm{pH}$ due to organic pulsation is due to the anaerobic decomposition process (lack of O2) which involves heterotrophic bacteria. In this process, sulfate and methane are formed which will contribute $\mathrm{H}+$ to the soil causing a decrease in $\mathrm{pH}$. In a more acidic atmosphere, nitrifying bacteria will have slower mobility in the decomposition process of organic matter, so that nutrients cannot be absorbed by plants (Puspitorini, 2020).

Based on the results of various treatments, various kinds of liquid organic fertilizers and kinds of organic mulch have a significant effect on the weight of 1000 seeds, this is because the use of rabbit urine fertilizer is expected to reduce the use of inorganic fertilizers, the continuous use of inorganic fertilizers is bad and not environmentally friendly.

Element $\mathrm{P}$ is available in sufficient quantities to spur the growth and development of a better root system. Conversely, if the plant is deficient in $\mathrm{P}$, the growth and development of the plant will decrease, because of the inhibition of the rate of photosynthesis. Also, the micronutrients contained in liquid organic fertilizers also play a role in the process of plant metabolism. Even though it is needed in small amounts, micronutrients still play an important role in determining the yield of soybean plants such as Phosphorus (P) which can accelerate flowering, ripen fruit and seeds, Potassium (K) which helps pods so that they do not fall off easily and Boron (B) which functions to increase the number of flowers which also results in the number of pods formed.

\section{CONCLUSION}

Based on the results of the observation that in general, in the treatment of various kinds of liquid organic fertilizers, which showed the best results were liquid organic fertilizer of rabbit urine (P3) compared to other liquid organic fertilizer treatments and in the treatment of various kinds of organic mulch, the best results were obtained with the use of organic mulch. (M1) compared to other organic mulches. So, the combination of treatment between rabbit urine liquid organic fertilizer and organic straw mulch (P3M1) can provide the best results on the growth and production of soybean.

\section{ACKNOWLEDGMENT}

Thank you to Darul Ulum Lamongan Islamic University for providing the opportunity and providing funds for the implementation of this research and to Malang Islamic University and Balitar Islamic University who have agreed to cooperate in this research.

\section{REFERENCES}

Amiroh, A. (2017). Kajian Perendaman Benih Dan Macam Pupuk Daun Terhadap Pertumbuhan Dan Produksi Tanaman Kedelai (Glycine Max. L. Merrill). Agroradix: Jurnal Ilmu Pertanian, 1(1), $1-15$.

Bardiana, D., Marliah, A., \& Sabaruddin, S. (2020). Pengaruh Residu Pembenah Tanah terhadap Serapan Hara dan Hasil Tanaman Kedelai (Glycine max L. Merril. Merrill). Jurnal Ilmiah Mahasiswa Pertanian, 5(1), 41-50. DOI:https://doi.org/10.17969/jimfp.v5i1 .1383 
Dewantari, R. P., Suminarti, N. E., \& Tyasmoro, S. Y. (2015). Pengaruh mulsa jerami padi dan frekuensi waktu penyiangan gulma pada pertumbuhan dan hasil tanaman kedelai (Glycine max (L.) Merril). Jurnal Produksi Tanaman, $3(6)$.

Gustia, H. (2017). Respon Tanaman Wortel Terhadap Pemberian Urine Kelinci. Jurnal Agrosains dan Teknologi, 1(1), 46-56.

DOI:https://doi.org/10.24853/jat.1.1.4656

Jayasumarta, D. (2015). Pengaruh sistem olah tanah dan pupuk $\mathrm{p}$ terhadap pertumbuhan dan produksi tanaman kedelai (Glycine max L. Merrill. Merrill). AGRIUM: Jurnal Ilmu Pertanian, 17(3). DOI:https://doi.org/10.30596/agrium.v1 7i3.313

Marliah A, Nurhayati, Dewi Susilawati. (2011). Pengaruh Pemberian Bahan Organik Terhadap Pertumbuhan, Produksi Tanaman Kedelai (Glycine max (L.) Merrill). J. Floratek 6: 192 201.

Muliartha, I N. and Purba, J.H. 2020. Potential of Loss of Organic Fertilizer in Lowland Rice Farming in Klungkung District, Bali. Agro Bali: Agricultural Journal, Vol. 3(2): 179-185. DOI: 10.37637/ab.v3i2.567.

Nurmasyitah, N., Syafruddin, S., \& Sayuthi, M. (2013). Pengaruh jenis tanah dan dosis fungi mikoriza arbuskular pada tanaman kedelai terhadap sifat kimia tanah. Jurnal Agrista, 17(3), 103-110.

Parmila, P., Purba, J.H. and Suprami, L. 2019. Pengaruh Dosis Petroganik dan Kalium terhadap Pertumbuhan dan Hasil Semangka (Citrulus vulgaris SCARD). Agro Bali: Agricultural Journal Vol. 2(1): 37-45.

Pradoto, R. W., Sebayang, H. T., \& Sumarni, T. (2017). Pengaruh Sistem Olah Tanah Dan Mulsa Organik Pada Pertumbuhan
Dan Hasil Tanaman Kedelai (Glycine Max (L.) Merril). Jurnal Produksi Tanaman, 5(1).

Purba, J.H., Wahyuni, P.S., Zulkarnaen, Sasmita, N., Yuniti IG.D., Pandawani, N.P. 2020. Growth and yield response of shallot (Allium ascalonicum L. var. Tuktuk) from different source materials applied with liquid biofertilizers. Nusantara Bioscience, Vol. 12 No. 2: 127-133.

Puspitorini,P. 2020. Dosis Hijauan dan Mulsa Pada Pertumbuhan dan Hasil Tanaman Okra (Abelmoschus esculentus L. Moench.). Jurnal Agrika Vol 14 No 1. DOI 10.31328/ja.v14i1.1270

Sembiring, M. Y., Setyobudi, L., \& Sugito, Y. (2017). Pengaruh dosis pupuk urin kelinci terhadap pertumbuhan dan hasil beberapa varietas tomat. Jurnal Produksi Tanaman, 5(1).

Sudarmin dan Delly Resiani. 2016. Interaksi Kompos Kotoran Sapi dan Mulsa Jerami padi Terhadap Hasil Kedelai Edamame di lahan Kering. Prosiding Seminar Hasil Penelitian Tanaman Aneka Kacang dan Umbi.

Suwarno, D, 2009. Simposium Nasional RAPI VIII . Potensi dan Masalah Sampah di Jawa Tengah (Studi Kasus Pengadaan Pupuk Organik Berkelanjutan)

Utami, W. R., Barunawati, N., \& Sitompul, S. M. (2020). Pengaruh Pupuk Kandang dan Nitrogen Terhadap Pertumbuhan dan Hasil Kedelai (Glycine max [L.] Merr.). Jurnal Produksi Tanaman, 8(1). DOI:https://doi.org/10.33059/jupas.v6i2 .1758 